\title{
PENELANTARAN ORANG TUA DALAM LINGKUP RUMAH TANGGA PERSPEKTIF HUKUM ISLAM DAN HUKUM POSITIF INDONESIA
}

\author{
Wardah Nuroniyah \\ wardah.faza17@gmail.com
}

\begin{abstract}
One of the acts of domestic violence against people in the household sphere is neglect. Parental neglect is negligence of the child towards the biological mother's father who has a dependency in physical needs (negligence to provide adequate food, clothing, or hygiene), and emotional (negligence to provide care or affection). neglect of parents is included in the form of lawlessness to parents because parents have rights to their children. So that for each perpetrator of neglect parents must be subject to sanctions.

This study aims to answer the questions that formulate the problem: "What is the view of Islamic law and positive law in Indonesia on neglect of parents" and "What are the sanctions for perpetrators of neglect of parents according to Islamic law and positive law in Indonesia". This study uses qualitative research, data collected by means of literature (library research) are then analyzed.

As for the results of this study: 1) Neglect of parents in Islamic law and in positive law in Indonesia is prohibited, because in Islamic law people who do neglect are sinful, while in positive law in Indonesia neglect is included in violence. 2) Sanctions for perpetrators of neglect of parents in the perspective of Islamic law and positive law in Indonesia are criminal sanctions, but in Islamic law it is called jarimah ta'zir and the sanctions are not only that but there are other sanctions, namely big sins, all deeds are not accepted by Allah SWT, will not enter heaven, hated by Allah SWT.
\end{abstract}

Keywords: Neglect, Parents, Sanctions, Islamic Law, Positive Law in Indonesia.

\section{Pendahuluan}

Kewajiban pemeliharaan dalam garis lurus dari pertalian-pertalian keluarga dapat timbul berbagai hubungan, dimana orang yang satu terhadap orang yang lain diwajibkan untuk memelihara atau mempunyai kewajiban alimentatie. Alimentatie berasal dari bahasa Itali yang berarti hukum tentang kewajiban suami atau kepala keluarga terhadap istri, orang tua terhadap anak, dan anggota keluarga lainnya (F.A.Vollmar, 1990). Pengaturan dan kewajiban-kewajiban alimentatie dalam Undangundang di Indonesia tidak diatur dalam suatu kesatuan yang bulat, akan tetapi terdiri dari pasal-pasal yang terpisah dari berbagai Undang-undang. Pelanggaran terhadap kewajiban alimentatie termasuk dalam tindakan kekerasan dalam rumah tangga.

Kekerasan dalam rumah tangga adalah setiap perbuatan terhadap anggota keluarga dalam rumah tangga yang mengakibatkan timbulnya kesengsaraan atau bahkan penderitaan secara fisik, psikologis, ekonomi, dan penelantaran dalam rumah tangga, termasuk ancaman untuk melakukan perbuatan, pemaksaan, atau perampasan kemerdekaan secara melawan hukum dalam lingkup rumah tangga. Kekerasan dalam rumah tangga tidak hanya berupa kekerasan fisik semata, meskipun akhir-akhir ini banyak sekali kejadian kekerasan dalam rumah tangga 
yang berupa kekerasan fisik. Baik yang menimpa istri, anak, pembantu rumah tangga (prt) atau orang lain yang masih dalam lingkup sebuah keluarga. Namun, penelantaran keluarga baik anak maupun istri ataupun yang lainnya yang akhir-akhir ini mulai banyak terjadi di masyarakat yang merupakan salah satu tindak pidana yang termasuk dalam Kekerasan Dalam Rumah Tangga (KDRT), hal tersebut telah tercantum dalam salah satu pasal yang terdapat dalam UU No 23 Tahun 2004 tentang Penghapusan Kekerasan Dalam Rumah Tangga.

Penelantaran rumah tangga juga termasuk dalam pengertian kekerasan, karena setiap orang dilarang menelantarkan orang dalam lingkup rumah tangga, padahal menurut hukum yang berlaku baginya atau karena persetujuan atau perjanjian ia wajib memberikan penghidupan, perawatan atau pemeliharaan kepada orang tersebut. Penelantaran tersebut juga berlaku bagi setiap orang yang mengakibatkan ketergantungan ekonomi dengan cara membatasi atau melarang untuk bekerja yang layak di dalam atau diluar rumah, sehingga korban di bawah kendali orang tersebut (Moerti Hadiati Soeroso, 2011).

Tindak pidana penelantaran orang lain dalam lingkup rumah tangga termasuk tindak pidana Kekerasan Dalam Rumah Tangga yang tergolong kekerasan psikologis dalam rumah tangga yang dapat mengakibatkan beban mental bagi korban pelaku tindak Kekerasan Dalam Rumah Tangga. Kekerasan Psikologis yang dilakukan pelaku terhadap korban memang tidak menimbulkan bekas luka seperti kekerasan fisik, namun kekerasan psikologis dapat menjatuhkan harga diri bahkan memicu dendam bagi korban terhadap pelaku. Kekerasan Psikologis bahkan lebih sulit diatasi daripada kekerasan fisik. Tindak pidana penelantaran dapat dipicu dari beberapa aspek, yakni diantaranya adalah tidak ada rasa tanggung jawab terhadap seseorang (anak/perempuan/orang tua), dan penelantaran ekonomi. Banyak pihak korban kekerasan penelantaran dalam Rumah Tangga tidak berani melaporkan tindakan tersebut lantaran takut membuka kejelekan atau aib keluarganya tersebut. Hal ini yang dapat memicu kurangnya perhatian terhadap perlindungan hak asasi perempuan atau anak.

Di Indonesia telah diberlakukan tentang undang-undang Kekerasan Dalam Rumah Tangga sejak tahun 2004. Misi dan undang-undang ini adalah sebagai ikhtiyar dan upaya dalam penghapusan kekerasan. Dengan adanya ketentuan ini, berarti negara bisa berupaya mencegah terjadinya kekerasan dalam rumah tangga, menindak pelaku Kekerasan Dalam Rumah Tangga, dan melindungi korban akibat KDRT. Sesuatu hal yang sebelumnya tidak bisa terjadi, karena dianggap sebagai persoalan internal keluarga seseorang. Secara tegas dikatakan bahwa, tindakan kekerasan fisik, psikologis, seksual, dan penelantaran rumah tangga (penelantaran ekonomi) yang dilakukan dalam lingkup rumah tangga merupakan tindak pidana. Tindakan-tindakan tersebut bisa terjadi antara pihak suami kepada isteri dan sebaliknya, atapun orang tua terhadap anaknya.

Sebagai undang-undang yang membutuhkan pengaturan khusus, selain berisikan pengaturan sanksi pidana, undang-undang ini juga mengatur tentang 
hukum acara, kewajiban negara dalam memberikan perlindungan segera kepada korban yang melapor. Dengan demikian, bisa dikatakan bahwa ketentuan ini adalah sebuah terobosan hukum yang sangat penting bagi upaya penegakan HAM, khususnya perlindungan terhadap mereka yang selama ini dirugikan dalam sebuah tatanan keluarga atau rumah tangga. Dalam UU PKDRT pasal 5 terdapat larangan melakukan kekerasan dalam rumah tangga terhadap orang dalam lingkup rumah tangganya, dengan cara kekerasan fisik, kekerasan psikis, kekerasan seksual dan penelantaran.

Secara bahasa kata penelantaran berasal dari kata telantar yang artinya dimana orang dewasa yang bertanggungjawab atas seseorang telah gagal untuk menyediakan kebutuhan memadai untuk berbagai keperluan, termasuk fisik (kegagalan untuk menyediakan makanan yang cukup, pakaian, ataukebersihan), emosional (kegagalan untuk memberikan pengasuhan atau kasih sayang) (Wikipedia.org). Menelantarkan adalah kelalaian dalam memberikan kebutuhan hidup pada seseorang yang memiliki kebergantungan kepada pihak lain, khususnya dalam lingkungan rumah tangga (Luhulima, 2000). Penelantaran adalah seseorang yang menurut hukum yang berlaku wajib memberikan perawatan atau pemeliharaan kepada orang yang dalam tanggung jawabnya, dan juga terhadap orang yang membatasi dan melarang untuk bekerja yang layak di luar rumah yang menyebabkan korban menjadi di bawah kendali orang tersebut (Sudira, 2016). berikut:

Dalam UU PKDRT, penelantaran diatur secara eksplisit dalam Pasal 9, sebagai

1. Setiap orang dilarang menelantarkan orang dalam lingkup rumah tangganya, padahal menurut bukum yang berlaku baginya atau karena persetujuan atau perjanjian ia wajib memberikan kebidupan, perawatan atau pemeliharaan kepada orang tersbut.

2. Penelantaran sebagaimana dimaksud ayat (1) juga berlaku bagi setiap orang yang mengakibatkan ketergantungan ekonomi dengan cara membatasi dan/atau melarang untuk. bekerja yang layak di dalam atau di luar rumah sehingga korban berada di bawah kendali orang tersebut.

Orang tua, menurut KBBI, adalah ayah ibu kandung, orang yang dianggap tua (cerdik pandai, ahli, dan sebagainya); orang-orang yang dihormati (disegani) di kampung. Dalam konteks keluarga, tentu saja orang tua yang dimaksud adalah ayah dan atau ibu kandung dengan tugas dan tanggung jawab mendidik anak dalam keluarga. Orang tua adalah ayah dan ibu, yang telah melahirkan, mengurus, dan membesarkan kita, hingga kita menjadi orang yang berguna. Sebab kata Al-walidain atau abawain yang ditemukan dalan nash hanya merujuk pada mereka berdua (Gunawan; 2014). Adapun yang dimaksud dalam artikel adalah orang tua yang cukup umur atau biasa disebut lansia.

Lansia adalah seseorang yang telah memasuki usia 60 tahun keatas. Lansia merupakan kelompok umur pada manusia yang telah memasuki tahapan akhir dari fase kehidupannya. Hal ini menimbulkan berbagai permasalahan yang dialami oleh lansia seperti tindak kekerasan, pelanggaran hukum, kemiskinan, hingga penelantaran 
lansia sehingga banyak lansia yang mengalami ketergantungan hidup terhadap orang lain dalam memenuhi hidupnya. Ketika memasuki usia tua para lansia mengalami perubahan struktuk otak yang menyebabkan kemunduran kualitas hidup yang berimplikasi pada kemandirian dalam melakukan aktivitas sehari-hari. Hal ini menimbulkan berbagai permasalahan yang dialami oleh lansia seperti tindak kekerasan, pelanggaran hukum, kemiskinan, hingga penelantaran lansia sehingga banyak lansia yang mengalami ketergantungan hidup terhadap orang lain dalam memenuhi hidupnya. Ketika memasuki usia tua para lansia mengalami perubahan struktuk otak yang menyebabkan kemunduran kualitas hidup yang berimplikasi pada kemandirian dalam melakukan aktivitas sehari-hari (Yudrik Jahja; 2011).

Perserikatan Bangsa-Bangsa memperkirakan bahwa ditahun 2050 jumlah warga lansia akan mencapai sekitar 60 juta jiwa, yang menyebabkan Indonesia berada pada peringkat ke 4 penduduk lansia terbanyak setelah China, India dan Amerika Serikat. Meningkatnya jumlah lansia menimbulkan masalah terutama dari segi kesehatan dan kesejahteraan lansia. Masalah tersebut jika tidak ditangani akan berkembang menjadi masalah yang kompleks dari segi fisik, mental dan sosial yang berkaitan dengan kesehatan dan kesejahteraan mereka. (Notoatmodjo; 2007)

Keluarga merupakan kebutuhan primer lansia dimana keluarga mempunyai peran penting untuk membantu lansia dalam memenuhi kebutuhan hidupnya. Dukungan dari keluarga merupakan kebutuhan utama yang dibutuhkan oleh lansia, dengan dukungan dari keluarga bisa membuat hidup para lansia menjadi teratur dan tidak berlebihan. Dukungan yang diberikan oleh keluarga seperti rasa cinta dan kasih sayang yang diberikan merupakan bagian asuhan dan perhatian dalam fungsi efektif keluarga. Keluarga seharusnya sebagai peran utama dalam merawat dan menjaga lansia, karena lansia sangat membutuhkan dukungan dari keluarga untuk menjalani kehidupan lansia, kalau dari keluarga sendiri tidak mendukung dan mejaga lansia maka keadaan lansia akan semakin kesusahan.

Perintah berbakti dan selalu berbuat baik kepada kedua orang tua adalah wajib atas seorang muslim dan salah satu bentuk ketaatan dalam rangka mendekatkan diri kepada Allah SWT. Bahkan di dalam al-Qur`an, Allah SWT. meletakkan perintah untuk berbakti dan berbuat baik kepada kedua orang tua setelah perintah mengesakan ibadah kepada Allah SWT dan setelah larangan untuk mempersekutukannya dengan sesuatu apapun (Q.S Al-Isra : 23). Dalam hal ini keluarga adalah garis utama pertahanan masyarakat terhadap pertumbuhan masalah penduduk lansia. Adapun penelantaran orang tua yang sudah lansia adalah kelalaian anak terhadap ayah ibu kandung yang memiliki ketergantungan dalam kebutuhan fisik (kelalaian untuk menyediakan makanan yang cukup, pakaian, atau kebersihan), dan emosional (kelalaian untuk memberikan pengasuhan atau kasih sayang). (Kansil; 2002)

Persoalan ini menarik dimana seharusnya lansia mendapatkan perhatian, perawatan serta kebahagiaan dengan keluarga dimasa-masa tuanya tetapi tidak sedikit sebuah keluarga yang lengah dan membiarkan orang tuanya menghadapi berbagai 
masalah yang mereka hadapi dengan sendiri, ada sebagian dari mereka yang merasa terlantar dan juga tidak mendapatkan kebahagian dengan keluarganya. Berdasarkan uraian-uraian yang telah dipaparkan di atas, maka penulis tertarik untuk mengkaji "Penelantaran Orang tua (Studi Komparatif Hukum Islam dan Hukum Positif Di Indonesia)". Bagaimana pandangan hukum Islam dan hukum positif di Indonesia terhadap penelantaran orang tua? Bagaimanakah sanksi terhadap pelaku penelantaran orang tua menurut hukum Islam dan hukum positif di Indonesia?

\section{Pembahasan dan Analisis}

\section{Hak Orang Tua Sebagai Kewajiban Anaknya}

Keluarga merupakan sebuah unit terkecil dalam masyarakat yang memiliki tujuannya sendiri. Tujuan tersebut merupakan tujuan yang hendak dicapai oleh setiap individu dalam keluarga. Dalam usaha untuk mencapai tujuan tersebut keluarga menjalankan peran sesuai fungsinya. Fungsi keluarga terbentuk oleh karena adanya interaksi, relasi dan interdependensi. Fungsi keluarga biasanya didefinisikan sebagai hasil atau konsekuensi dari struktur keluarga. Menurut Friedman fungsi keluarga secara umum dibagi menjadi lima fungsi: (Effendy; 2009) yaitu fungsi afektif, sosialisasi, reproduksi, ekonomi dan fungsi perawatan atau pemeliharaan. Fungsi afektif (the affective function) merupakan fungsi keluarga yang utama, yang berhubungan erat dengan fungsi internal keluarga. Ini merupakan basis kekuatan keluarga, karena berkaitan dengan setiap individu yang ada di dalam keluarga. Fungsi ini dibutuhkan untuk perkembangan individu dan psikososial anggota keluarga. Keberhasilan fungsi ini dapat terlihat pada pencapaian kebahagian dari seluruh anggota keluarga. Tiap anggota keluarga saling mempertahankan iklim yang positif dalam keluarga, perasaan memiliki, perasaan yang berarti dan merupakan sumber kasih sayang. Keluarga yang berhasil melaksanakan fungsi afektif ini juga ditandai dengan keberhasilan dari seluruh anggota keluarga untuk dapat mengembangkan konsep diri yang positif. Perceraian, kenakalan anak, pertikaian dalam rumah tangga dan persoalan-persoalan keluarga lainnya sering muncul akibat dari tidak terpenuhinya fungsi afektif dalam keluarga. Dalam konteks Indonesia, fungsi keluarga dapat mengacu pada UU No.10 tahun 1992 jo PP No.21 tahun 1994, yaitu: fungsi keagamaan, budaya, cinta kasih, perlindungan, reproduksi, sosialisasi, ekonomi dan pelestarian lingkungan. Intinya, fungsi keluarga yang diuraikan hampir serupa dengan teori Friedman, hanya saja fungsi afektif diartikulasikan sebagai fungsi keagamaan dan kebudayaan. Manusia menyerap nilai-nilai keagamaan dan budaya menjadi dimensi afektif dalam dirinya. Fungsi keagamaan yang dimaksud di sini adalah, bagaimana keluarga dapat membina norma ajaran-ajaran agama sebagai dasar dan tujuan hidup seluruh anggota keluarga, menerjemahkan agama ke dalam tingkah laku hidup seharihari kepada seluruh anggota keluarga, memberikan contoh konkrit dalam hidup sehari-hari dalam pengamalan dari ajaran agama, melengkapi dan menambah proses kegiatan belajar anak tentang keagamaan yang kurang diperolehnya di sekolah atau masyarakat, serta membina rasa, sikap, dan praktik kehidupan keluarga beragama 
sebagai pondasi menuju keluarga kecil bahagia sejahtera. Sementara fungsi budaya adalah membina tugas-tugas keluarga sebagai lembaga untuk meneruskan normanorma dan budaya masyarakat dan bangsa yang ingin dipertahankan. Keluarga menjadi bagian dari masyarakat kultur, sehingga nilai-nilai budaya tidak dapat diabaikan begitu saja. Persoalan budaya berkaitan dengan kearifan lokal di mana keluarga ada, bahkan pada bagian yang lebih besar berbicara tentang nilai kebangsaan. Moral keluarga harus mencerminkan nilai ideologi kebangsaan Indonesia yang tentu didukung oleh pranata budaya. Hal ini seperti yang diungkapkan oleh “....keluarga serta pranata keagamaan berperan sebagai pemelihara kehidupan moral." Melalui penjabaran fungsi-fungsi keluarga di atas, maka dapat disimpulkan bahwa keluarga adalah tempat pertama dan utama di mana seorang pribadi bertumbuh, berkembang, menerima pendidikan dan yang berikutnya dia akan menerima perlindungan baik secara ketenangan batin ataupun keagamaan dan terbangunnya ikatan antara pribadi yang akan terwujud hingga anggota keluarga tersebut memasuki fase lanjut usia.

Friedman berpendapat bahwa studi-studi tentang dukungan keluarga telah mengkonseptualisasi dukungan sosial, baik dukungan yang bersifat eksternal maupun internal terbukti sangat bermanfaat. "Dukungan keluarga eksternal antara lain sahabat, pekerjaan, tetangga, sekolah, keluarga besar, kelompok social, kelompok rekreasi, tempat ibadah dan praktisi kesehatan. Dukungan keluarga internal antara lain dukungan dari suami atau istri, dari saudara kandung atau dukungan dari anak." Berdasarkan pandangan tersebut maka keluarga menjadi tempat pertama bagi seorang individu untuk mendapatkan topangan ataupun dorongan dalam menghadapi berbagai proses. Bagi seorang yang telah memasuki masa lanjut usia, berbagai perubahan yang dialami akan menimbulkan persoalan tersendiri yang terkadang akan dapat berpengaruh dalam kesehatan fisiknya ataupun keseimbangan mental psikologisnya. Tidak jarang karena perubahan-perubahan yang dialami oleh seorang lanjut usia juga akan berdampak kepada kerohaniannya. Karena kondisi inilah, maka keluarga menjadi tempat pertama bagi seorang lanjut usia untuk dapat memasuki proses penerimaan diri terhadap perubahan-perubahan kehidupan dan itulah sebabnya dukungan keluarga sangat dibutuhkan. "Dukungan keluarga merupakan bantuan yang dapat diberikan kepada keluarga lain berupa barang, jasa, informasi dan nasehat, yang mana membuat penerima dukungan akan merasa disayang, dihargai, dan tentram." Menurut Sarwono "dukungan adalah suatu upaya yang diberikan kepada orang lain, baik moril maupun materil untuk memotivasi orang tersebut dalam melaksanakan kegiatan." dukungan keluarga sangat erat hubungannya dengan salah satu fungsi dasar keluarga, yaitu fungsi afektif, di mana keluarga menjadi tempat untuk pemenuhan kebutuhan psikososial, saling mengasuh dan memberikan cinta kasih, serta saling menerima dan mendukung. "Menurut Friedman, dampak positif dari dukungan keluarga adalah meningkatkan penyesuaian diri seseorang terhadap kejadian-kejadian dalam kehidupan".

Makna menghormati orang tua bukan hanya sekadar menggunakan ucapan dan bahasa tubuh yang penuh hormat terhadap orang tua serta menaati mereka 
dengan penuh sukacita dan kerelaan, tetapi juga menghormati mereka dengan subtansi yang ada, memenuhi kebutuhan mereka akan sandang, pangan dan kebutuhan hidup lain yang mereka butuhkan; yang dilakukan sebagai sebuah pelayanan seorang anak terhadap orang tuanya yang memang sudah sepantasnya mereka terima, sebagai balasan atas biaya dan perhatian yang telah mereka berikan serta berbagai masalah yang harus mereka hadapi tatkala orang tua membesarkan anak-anak mereka di dunia. Artinya, makna kata "hormatilah" memiliki pengertian yang bukan hanya berbicara tentang sikap ataupun tindakan seorang anak kepada orang tuanya pada saat orang tuanya masih kuat dan mampu menanggung hidup keluarga, terlebih lagi adalah pada saat orang tua sudah tidak lagi memiliki kekuatan seperti pada masa lampau. Perintah untuk menghormati orang tua justru termasuk pada waktu kondisi orang tua sudah harus hidup bergantung kepada anak-anaknya. Menghormati orang tua melibatkan penghargaan, hormat dan dukungan. Itu berarti juga tanggungjawab untuk keluarga ada untuk mereka dan tetap memperhatikan mereka melalui pelayanan, dukungan, keuangan, kunjungan. Dengan demikian dalam teks "hormatilah ibu bapamu" terkandung makna bahwa bentuk penghormatan itu meliputi dukungan dalam segala segi, khususnya pada waktu orangtua telah memasuki masa usia lanjut dan tidak memiliki kekuatan fisik ataupun materi (Ihromi; 1999).

Peranan keluarga dalam memelihara dan meningkatkan kesehatan setiap anggota keluarga serta dalam menjamin keberhasilan pelayanan keluarga amat penting sekali, karena keluarga memang punya arti dan kedudukan tersendiri dalam masalah kesehatan (Azwar; 2007). Kualitas hidup lansia merupakan suatu komponen yang kompleks dimana mencakup tentang usia harapan hidup, kepuasan dalam kehidupan, kesehatan psikis dan mental, fungsi kognitif, kesehatan dan fungsi fisik, pendapatan, kondisi tempat tinggal, dukungan sosial dan jaringan sosial. Di Indonesia para lansia biasanya tinggal bersama anaknya terutama lansia yang sudah tidak mendapatkan penghasilan sendiri (Nawi; 2010).

Fungsi keluarga yang sehat akan menyebabkan kualitas hidup anggota keluarganya menjadi baik. Penilaian dari kualitas hidup dapat dinilai dari 4 bidang yaitu fisik, psikis, sosial dan lingkungan. Bila fungsi keluarga tidak sehat maka akan dapat meningkatkan angka kesakitan dan angka kematian yang akhirnya akan menurunkan kualitas hidup..Pada suatu penelitian ditemukan bahwa kualitas hidup lansia ditemukan rendah pada keadaan pendidikan yang rendah, sosio ekonomi rendah, tidak menikah atau sudah hidup sendiri (pasangannya meninggal atau bercerai) dan kesehatannya terganggu, (Nawi, 2010)

Hak dan kewajiban adalah dua sisi dari hal yang sama (dari hubungan hukum yang sama) dan karena itu tak dapat dipisahkan. Dengan menamakan hukum subjektif sebagai hak. Hukum subjektif adalah suatu hubungan yang diatur oleh hukum objektif, berdasarkan mana yang satu mempunya hak, yang lain mempunyai kewajiban. Hak-hak yang diberikan oleh hukum subjektif, dapat berbentuk dua. Pertama-tama ia dapat terdiri atas hak untuk menuntut agar orang lain bertindak, artinya berbuat sesuatu atau tidak berbuat sesuatu. Kebalikan dari pada hak ini, ialah 
kewajiban dari orang lain untuk bertindak (Apeldoorn; 1996).

Dilarangnya penelantaran orang tua ialah karena kedua orang tua memiliki hak dari anak-anaknya baik menurut hukum Islam ataupun menurut positif di Indonesia. Hak kepada kedua orang tua atas anak adalah taat kepada orang tua atau berbakti kepada orang tua (birrul walidain), sesuai dengan perintah Allah SWT dan Rasul-Nya, selama keduanya tidak memerintahkan untuk berbuat maksiat atau hal-hal yang tidak sesuai dengan aturan atau syariat Allah SWT dan Rasul-Nya. Sebagaimana dalam firman Allah SWT (QS. Al-Ankabut (29): 8. Berikut adalah bentuk-bentuk birrul walidain: (Jawas, 2018)

1. Bergaul bersama keduanya dengan cara yang baik.

Dalam sebuah riwayat dikatakan bahwasannya ketika seseorang datang untuk membaiat Rasulullah SAW atas hijrah dengan meninggalkan orang tuanya dalam keadaan menangis, Rasulullah SAW bersabda dalam HR. Abu Dawud (no. 2166), an-Nasai (VII/143), al-Hakim (IV/152) dan al-Baihaqi (IX/26), dari Abdullah bin Amr bin al-Ash ra:

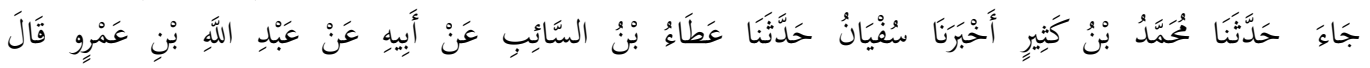

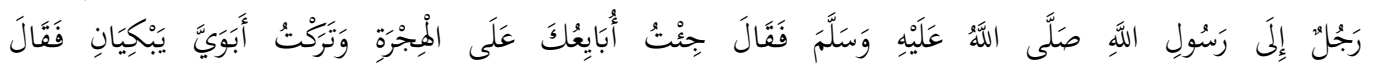

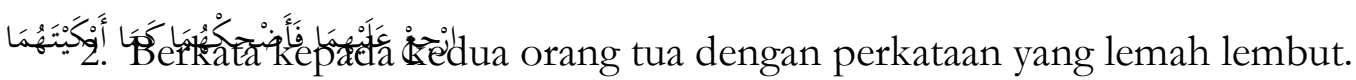

Hendaknya dibedakan antara berbicara dengan kedua orang tua dan berbicara dengan anak, teman, atau dengan yang lainnya. Berbicara dengan perkataan yang mulia kepada kedua orang tua merupakan keharusan, tidak boleh mengucap 'ah' apalagi mencemooh dan mencaci maki atau melaknat keduanya karena ini merupakan dosa besar dan bentuk kedurhakaan kepada orang tua. Berikut adalah firman Allah SWT QS. Al-Israa' (17): 23.

3. Tawadu (rendah hati)

Tidak boleh kibir (sombong), tidak boleh angkuh dengan orang tua, jangan merasa tinggi hati dengan sebab sudah meraih kesuksesan atau mempunyai jabatan di dunia, karena sewaktu lahir kita berada dalam keadaan hina dan butuh pertolongan. Allah SWT yang menolong kita, kemudian kedua orang tualah yang menolong dengan memberi makan, minum, pakaian, dan semuanya. Berikut firman Allah SWT tentang perintah rendah hati dalam QS. Asy-Syu'ara' (26): 215.

4. Memberi infak atau nafkah kepada kedua orang tua sesuai dalam QS. AlBaqarah (2): 215. Seseorang yang sudah berkecukupan dalam harta, hendaklah ia menafkahkannya pertama kali pada kedua orang tua. Dan kedua orang tua memiliki hak tersebut, seperti firman Allah SWT dalam surat AlBaqarah di atas. Kemudian kaum karib kerabat, anak yatim, dan orang-orang yang dalam perjalanan. Berbuat baik pertama adalah kepada ibu lalu ayah, kemudian kepada yang lain; sebagaimana Rasulullah SAW bersabda dalam HR. Bukhari (no. 5514), dan Muslim (no. 4621 dan 4622):

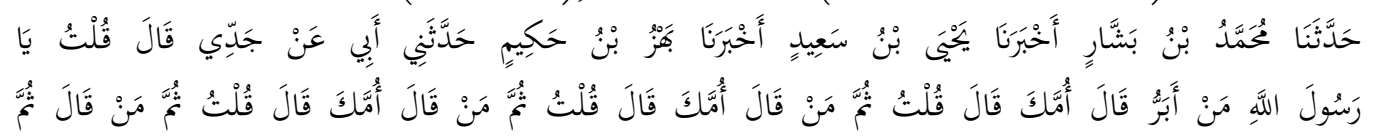

70 Pusat Studi Gender dan Anak (PSGA) UIN Mataram 


\section{Qawwãm — Volume 13 Nomor 1, Juni 2019}

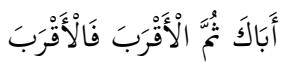

Berkenaan dengan nafkah untuk orang tua dan kerabat terdapat penjelasan yang rinci dari masing-masing mazhab sebagai berikut (al-Jaziri; 2017):

a. Mazhab Hanafi

Nafkah orang tua wajib bagi anak-anak mereka. Anak wajib memberikan nafkah untuk ayah, kakek dari jalur ayah, kakek dari jalur ibu, dengan syarat mereka miskin. Ayah yang sudah tua tidak diharuskan bekerja sebagaimana anak. Seperti itu juga ibu. Bila anak mampu memberikan makanan untuk salah satunya, ibu yang harus didahulukan atas ayah. Bila anak mengaku bahwa ayahnya kaya, ia harus membuktikannya. Bila anak tidak memiliki bukti, berarti perkataan ayah dibenarkan. Bila ayah memiliki anak lelaki dan anak perempuan yang sama-sama kaya, nafkah ayah dibagi di antara mereka berdua secara sama, meski salah satu dari keduanya lebih kaya dari yang lainnya. Memang, bila berbeda di antara keduanya terpaut banyak, saat itu anak yang kaya memberi jatah lebih banyak.

Anak yang kaya wajib juga menanggung nafkah istri ayahnya (ibu tiri). Anak juga harus menikahkan ayah (bila ia tidak punya istri dan ingin menikah). Bila ayah memiliki istri lebih dari satu, anak hanya wajib menanggung nafkah satu istri ayahnya yang diserahkan (nafkah tersebut) kepada ayah.

b. Mazhab Maliki

Nafkah untuk kedua orang tua wajib bagi anak-anaknya dengan beberapa syarat sebagai berikut:

1) Anak berstatus merdeka. Nafkah orang tua tidak wajib bagi anak yang berstatus budak.

2) Kedua orang tua miskin, maksudnya tidak mampu memcukupi keperluan mereka sendiri. Bila mereka mampu untuk salah satu saja, anak wajib menutupi keperluan yang satunya.

3) Keduanya tidak mampu bekerja. Bila keduanya mampu bekerja, nafkah mereka tidak wajib bagi anak dan keduanya dipaksa agar bekerja.

4) Anak kondisinya kaya pada saat itu. Bila yang bersangkutan kaya jikalau mau bekerja, artinya mampu bekerja, ia tidak dipaksa agar bekerja untuk orang tuanya, sebagaimana ayah tidak dipaksa untuk bekerja agar memberi nafkah anak.

5) Keduanya terbukti miskin berdasarkan kesaksian dua orang adil. Tidak cukup dengan satu orang adil dan sumpah, juga tidak cukup satu lelaki adil dan dua orang perempuan. Bila anak mengaku miskin, apakah ia harus membuktikan atau apakah orang tua yang harus membuktikannya? Menurut sebagian fuqaha tidak jelas dalam hal ini. Ada yang menyatakan, anak harus membuktikannya. Yang lain berkata, keduanya harus membuktikannya. 
6) Uang yang dimiliki anak lebih dari keperluan makanan untuk pribadi, istri, anak-anak, binatang piaraan, dan pembantu yang diperlukan. Bila tidak ada lebihan uang sama sekali, anak tidak wajib menanggung nafkah orang tuanya. Nafkah untuk orang tua tidak disyaratkan harus agamanya Islam.anak muslim wajib menanggung nafkah ayahnya yang kafir, dan sebaliknya. Wajib bagi anak yang kaya untuk memberi nafkah pembantu kedua orang tuanya meski orang tuanya tidak memerlukan pembantu, berbeda dengan pembantu anak orang tua tidak wajib menafkahi pembantu anak. Anak kaya juga wajib memberi nafkah untuk pembantu ibu tirinya bila memang layak diberi pembantu.

c. Mazhab Asy-Syafi'i

Anak wajib memberi nafkah untuk kedua orang tua dengan beberapa syarat sebagai berikut:

1) Kedua orang tua miskin, tidak memiliki makanan, lauk, dan tempat tinggal yang layak. Nafkah yang diberikan tidak wajib terlalu kenyang.

2) Anak kondisinya mampu, meski dengan pekerjaan yang baik, baik untuk anak lelaki maupun anak perempuan.

3) Anak memiliki harta lebih dari keperluan pribadi, keperluan istri, dan anak-anak selama sehari semalam. Bila tidak memiliki kelebihan harta, nafkah orang tua tidak wajib baginya. Kedua orang tua tidak disyaratkan tidak mampu bekerja, juga tidak disyariatkan Islam. Bila keduanya kafir dan anaknya muslim atau sebaliknya, nafkah tetap wajib ia tanggung.

d. Mazhab Hambali

Anak wajib memberikan nafkah untuk kedua orang tua dan seterusnya (kakek, buyut, dan seterusnya), sebagaimana ayah wajib memberikan nafkah untuk anak dan seterusnya (cucu, cicit, dan seterusnya) dengan ukuran yang baik bagi mereka berdasarkan kebiasaan, dengan tiga syarat sebagai berikut:

1) Yang diberi nafkah adalah orang-orang miskin, tidak memiliki harta dan penghasilan yang mencukupi keperluan mereka. Bila mereka memiliki harta atau meiliki pekerjaan yang mencukupi, berarti mereka tidak berhak mendapatkan nafkah. Bila mereka memiliki sebagian uang untuk mencukupi sebagian uang untuk mencukupi sebagian kebutuhannya saja, anak wajib menutupi kebutuhan lainnya.

2) Anak termasuk orang wajib menggung nafkah, dengan syarat hartanya lebih dari keperluan pribadi dan istri, baik berasal dari hartanya atau penghasilannya. Bagi yang tidak memiliki kelebihan harta sedikit pun, iia tidak wajib menanggung nafkah orang tua.

3) Yang memberi nafkah adalah pewaris dari yang diberi nafkah, baik waris dengan ketentuan atau dengan ashabah bila bukan berasal dari tiang nasab. Tiang nasab menghalangi meski tidak mewarisi. Karena itu, anak harus memberi nafkah untuk ayahnya yang miskin untuk istri ayahnya, untuk saudara-saudaranya yang masih kecil. 
5. Mendoakan kedua orang tua sesuai dalam QS. Al-Isra' (17): 24). Menurut tafsir Ibnu Katsir adalah "Dan rendabkanlah dirimu terhadap mereka berdua dengan penub kasib sayang," yaitu bertawadulah kepada keduanya melalui tindakanmu, "dan ucapkanlah, "wahai tubanku, kasibilab mereka berdua, sebagaimana mereka berdua telah mendidik aku ketika kecil," yaitu rahmatilah keduanya pada saat tua dan setelah mati (Najib ar-Rifa'i; 2012).

Dari Abu Hurairah ra. dari Rasulullah SAW, beliau bersabda HR. Muslim (no. 3084):

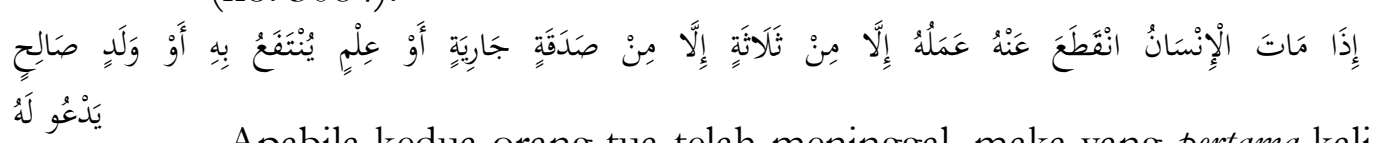

Apabila kedua orang tua telah meninggal, maka yang pertama kali harus kita lakukan adalah meminta ampun kepada Allah SW'T dengan taubat yang nashuh (benar) bila kita pernah berbuat durhaka kepada kedua orang tua sewaktu mereka masih hidup. Selanjutnya, mendoakan kedua orang tua kita. Disebutkan di dalam sebuah hadits da'if (lemah) yang diriwayatkan oleh Ibnu Majah dan Ibnu Hibban, seseorang pernah bertanya kepada Rasulullah SAW; "Apakah ada suatu kebaikan yang harus kuperkuat kepada kedua orang tuaku sesudah keduanya wafat?"

Nabi Muhammad SAW lantas menjawab: "Ya, kamu shalat atas keduanya (mendoakan keduanya), kamu memohon ampun untuk keduanya, memenuhi janji keduanya, menyambung silaturahim kepada orang yang dia pernah menyambung silatirahim kepadanya, dan memulikan teman-temannya"

Hadits ini dilemahkan oleh beberapa imam ahli hadits, karena dalam sanadnya ada seorang perawi yang majbul (atau tidak dikenal), yaitu Ali bin Ubaid as-Sa'idi. Syaikh al-Albani ra. melemahkan hadits ini dalam tahqiq Misykatul Mashabih, juga dalam Tahqiq Riyadhish Shalibin. Sedangkan menurut hadits-hadits yang shahih, amal-amal yang bisa diperbuat untuk orang tua yang sudah wafat antara lain (Qadir Jawas; 2018):

a. Mendoakannya,

b. Menshalatkan ketika keduanya meninggal,

c. Selalu meminta ampun untuk keduanya,

Ada orang tua yang diangkat derajatnya dalam surga disebabkan oleh anaknya yang senantiasa memohonkan ampunan kepada Allah SWT untuk keduanya. Rasulullah SAW bersabda dalam HR. Ahmad (II/509) dan Ibnu Majah (no. 3660), dari Abu Hurairah ra.:

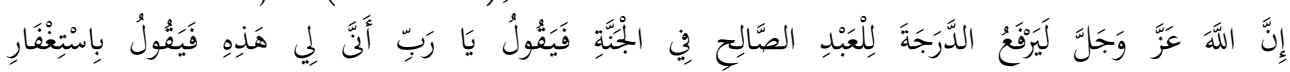

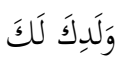

d. Membayarkan utang-utangnya,

Sungguh, roh seorang mukmin tergantung dengan sebab utangnya, maka sebaiknya (jika memiliki utang) baik kepada Allah SWT maupun kepada sesama manusia segera dilunasi. Hal ini dikarenakan ketika seseorang meninggal dunia, sementara ia masih memiliki hutang, maka 
utang tersebut akan menghalangi seseorang menuju surga (Gunawan; 2014). Rasulullah SAW bersabda dalam HR. At-Tirmidzi (no. 1078-1079) dan Ibnu Majah (no. 2413):

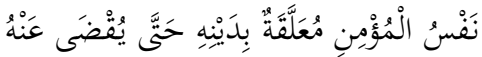

e. Menunaikan wasiat yang sesuai dengan syariat,

Orang tua yang telah meninggal dunia kemudian memiliki perjanjian atau pesan (wasiat) yang belum ditunaikan, maka seorang anak terlebih dahulu menunaikan perjanjian atau wasiatnya. Bahkan sebelum harta pusaka itu dibagikan. Karena hal itu semua merupakan utang yang musti dibayarkan.

Diriwayatkan dari Syaried bin Suwaid Ats- Tsaqafi, ia menuturkan: "Wahai Rasulullah, ibuku pernah berpesan (berwasiat) kepadaku untuk memerdekakan seorang budak wanita yang beriman. Aku memiliki seorang budak wanita berkulit hitam. Apakah aku harus memerdekakannya? Panggil dia, sabda Rasulullah SAW. Saat wanita itu datang, beliau bertanya: siapa Rabbmu? Budak wanita itu menjawab: Allah. Lalu siapa aku? Tanya Rasulullah SAW lagi. Wanita itu menjawab: engkau adalah Rasulullah SAW. beliau pun bersabda: merdekakan dia! Karena dia adalah wanita mukminat (yang beriman).

f. Menyambung tali persahabatan dengan orang yang keduanya biasa menyambungnya.

Hal ini sebagaimana hadits Rasulullah SAW dari sahabat Abdullah bin Umar ra, bahwasanya beliau mendengar Rasulullah SAW bersabda dalam HR. Muslim (no. 2552 (13):

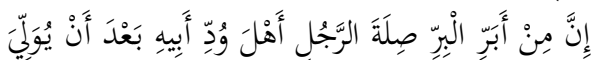

Sedangkan dalam hukum positif di Indonesia hak orang tua dari anaknya yaitu

Pertama, dalam Pasal 46 ayat (1) dan (2) Undang-Undang No. 1 Tahun 1974 tentang perkawinan:

(1) Setiap anak wajib hormat dan patub kepada orang tuanya,

(2) Anak yang telah dewasa wajib memelihara orang tua dan keluarganya menurut garis lurus ke atas yang dalam keadaan tidak mampu".

Kedua, dalam Pasal 19 Undang-Undang No. 23 tahun 2002 tentang perlindungan anak:

"Setiap anak berkewajiban untuk:

a. menghormati orang tua, wali, dan guru;

b. mencintai keluarga, masyarakat, dan menyayangi teman;

c. mencintai tanah air, bangsa, dan negara;

d. menunaikan ibadah sesuai dengan ajaran agamanya; dan

e. melaksanakan etika dan akblak yang mulia

Ketiga, dalam Pasal 298 KUHPer:

"Setiap anak, berapa pun juga umurnya, wajib menghormati dan menghargai orang tuanya". 
Keempat, dalam Pasal 321 KUHPer:

"Setiap anak wajib memberikan nafkah orang tua dan keluarga sedarahnya dalam garis ke atas, bila mereka ini dalam keadaan miskin".

Kelima, dalam Pasal 326 KUHPer:

"Bila orang yang wajib memberikan nafkah membuktikan ketidak mampuannya menyediakan uang untuk keperluan itu, maka pengadilan negeri adalab berkuasa, setelah menyelidiki duduk perkara, memerintabkan kepadanya supaya menempatkan pihak yang membutubkan nafkah dalam rumahnya dan memberikan kepadanya barang seperlunya".

Keenam, dalam Pasal 327 KUHPer:

"Bila bapak atau ibu menawarkan untuk memberi nafkah dan memelihara dirumahnya anak yang wajib diberinya nafkah, maka ia karena itu terbebas dan keharusan untuk memenubi kewajiban itu dengan cara lain".

Ketujuh, dalam Pasal 328 KUHPer:

"Anak di luar kawin yang diakui menurut undang-undang wajib memelihara orang tuanya kewajiban ini berlaku timbal-balik".

Kedelapan, dalam Pasal 329 KUHPer:

"Perjanjian-perjanjian di mana dilepaskan hak untuk menikmati nafkah adalah batal dan tidak berlaku".

Sedangkan aturan tentang Hak dan kewajiban orang tua dan anak dalam hukum positif di Indonesia dijelaskan sebagai berikut:

Pertama, dalam Pasal 46 ayat (1) dan (2) Undang-Undang No. 1 Tahun 1974 tentang perkawinan:

1. Setiap anak wajib hormat dan patuh kepada orang tuanya,

2. Anak yang telah dewasa wajib memelihara orang tua dan keluarganya menurut garis lurus ke atas yang dalam keadaan tidak mampu".

Kedua, dalam Pasal 19 Undang-Undang No. 23 tahun 2002 tentang perlindungan anak:

"Setiap anake berkewajiban untuk:

a. menghormati orang tua, wali, dan guru;

b. mencintai keluarga, masyarakat, dan menyayangi teman;

c. mencintai tanah air, bangsa, dan negara;

d. menunaikan ibadah sesuai dengan ajaran agamanya; dan

e. melaksanakan etika dan akblak yang mulia

Ketiga, dalam Pasal 298 KUHPer: "Setiap anak, berapa pun juga umurnya, wajib menghormati dan menghargai orang tuanya".

Keempat, dalam Pasal 321 KUHPer: "Setiap anak wajib memberikan nafkah orang tua dan keluarga sedarabnya dalam garis ke atas, bila mereka ini dalam keadaan miskin".

Kelima, dalam Pasal 326 KUHPer: "Bila orang yang wajib memberikan nafkah membuktikan ketidak mampuannya menyediakan uang untuk keperluan itu, maka pengadilan negeri adalah berkuasa, setelah menyelidiki duduk, perkara, memerintabkan kepadany a supaya menempatkan pibak yang membutubkan nafkah dalam rumahnya dan 
memberikan kepadanya barang seperlunya".

Keenam, dalam Pasal 327 KUHPer: "Bila bapak atau ibu menawarkan untuk memberi nafkah dan memelihara dirumahnya anak yang wajib diberiny a nafkah, maka ia karena itu terbebas dan keharusan untuk memenubi kewajiban itu dengan cara lain".

Ketujuh, dalam Pasal 328 KUHPer: "Anak di luar kawin yang diakui menurut undang-undang wajib memelihara orang tuanya kewajiban ini berlaku timbal-balik".

Kedelapan, dalam Pasal 329 KUHPer: "Perjanjian-perjanjian di mana dilepaskan bak untuk menikmati nafkah adalah batal dan tidak berlaku".

Adapun batas umur anak yang dianggap dewasa adalah:

1. Dalam Pasal 47 ayat (1) Undang-Undang Nomor 1 Tahun 1974 Tentang Perkawinan, yang berbunyi "Anak yang belum mencapai umur 18 (delapan belas) tahun atau belum pernah melangsungkan perkawinan ada di bawah kekuasaan orang tuanya selama mereka tidak dicabut dari kekuasaannya."

2. Dalam Pasal 330 KUHPer, yang berbunyi "Yang belum dewasa adalah mereka yang belum mencapai umur genap dua pulub satu tabun dan tidak kawin sebelumnya. Bila perkawinan dibubarkan sebelum umur mereka genap dua pulub satu tahun, maka mereka tidak kembali berstatus belum dewasa. Mereka yang belum dewasa dan tidak di bawah kekuasaan orang tua, berada di bawah perwalian atas dasar dan dengan cara seperti yang diatur dalam Bagian 3, 4, 5 dan 6 dalam bab ini."

3. Dalam Pasal 1 ayat 1 Undang-Undang No. 23 Tahun 2002 tentang perlindungan anak, yang berbunyi "anak adalah seseorang yang belum berusia 18 (delapan belas) tahun, termasuk anak yang masih dalam kandungan."

4. Dalam Pasal 15 ayat (1) dan (2) Kompilasi Hukum Islam (KHI), yang berbunyi

"(1)untuk kemaslahatan keluarga dan rumah tangga perkawinan hanya boleh dilakukan calon mempelai yang telah mencapai umur yang ditetapkan dalam Pasal 7 Undang-undang No. 1 Tabun 1974 yakni calon suami sekurangkurangnya berumur 19 tabun dan isteri sekurang-kurangnya berumur 16 tabun. (2) bagi calon mempelai yang belum mencapai umur 21 tahun harus mendapat izin sebagaimana yang diatur dalam Pasal 6 ayat (2), (3), (4), dan (5) UU No. 1 Thun 1974."

5. Dalam hukum Islam (al-Jaiziri, 2017), cara mengetahui balignya anak adalah sebagai berikut:

a. Menurut mazhab Hanafi, kondisi balig pada laki-laki diketahui mimpi basah, keluar air mani, dan mencintai wanita (lawan jenis). Sedangkan untuk wanita melalui haid dan hamil. Jika semuanya itu belum dialami olehnya maka untuk mengetahui 
kondisi balignya melalui umur. Laki-laki telah balig kalau umurnya genap 18 tahun, sedangkan perempuan 17 tahun.

b. Menurut mazhab Maliki, kondisi balig diketahui melalui beberapa hal yaitu keluar air mani, haid bagi wanita, tumbuh bulu di sekitar kemaluan, ketiaknya bau, mekarnya ujung hidung, membesarnya suara.

c. Menurut mazhab Syafi'i, kondisi balig anak laki-laki dan perempuan dapat diketahui melalui genapnya ia berumur 15 tahun. Tanda lain ialah keluar air mani. Keluar mani tidak menjadi alamat balig kecuali jika anak genap berumur 9 tahun. Tanda lain adalah haid bagi wanita, ia bisa terjadi ketika berusia / kerang lebih 9 tahun.

d. Menurut mazhab Hambali, anak laki-laki maupun perempuan, balignya dapat diketahui melalui 3 cara yaitu keluarnya air mani, tumbuhnya bulu kasar pada sekitar kemaluan, ketika berumur 15 tahun, dan untuk wanita terdapat tambahan haid dan hamil.

\section{Penelantaran Orang Tua dan Sanksinya Bagi Pelaku Perspektif Hukum Islam Dan Hukum Positif Di Indonesia.}

Penelantaran orang tua adalah kelalaian anak yang telah cakap hukum terhadap ayah ibu kandung yang memiliki ketergantungan dalam kebutuhan fisik (kelalaian untuk menyediakan makanan yang cukup, pakaian, atau kebersihan), dan emosional (kelalaian untuk memberikan pengasuhan atau kasih sayang).

Bentuk-bentuk penelantaran kepada orang tua (al-Ghamidi; 2010)

1. Penelantaran mental, terjadi ketika si anak tidak memperdulikan dan kurang merawat kedua orang tua, serta menitipkan mereka di Panti Jompo.

2. Penelantaran fisik, katika si anak menunda-nunda pengobatan mereka, maksudnya tidak segera merawat dan mengobati mereka sehingga tidakkan tersebut berpotensi memperparah, dan melanggengkan penyakit yang ada ditubuh mereka.

3. Penelantaran materi, terjadi ketika si anak yang berharta banyak tidak memberikan nafkah kepada orang tuanya yang kekurangan, menekan kebutuhan hidup mereka dan menguasai aset-aset mereka tanpa seizin mereka.

4. Penelantaran fasilitas medis, ketika si anak memperpanjang masa inap mereka di Rumah Sakit, maksudnya dengan memberikan fasilitas yang murah padahal anak tersebut mampu secara ekonomi, serta tidak ada keinginan untuk mengeluarkan mereka dari sana.

Dalam hukum positif di Indonesia penelantaran orang tua termasuk dalam tindakkan kekerasan sabagaimana tertera dalam UU No. 23 tahun 2004 PKDRT pasal 5 terdapat larangan melakukan kekerasan dalam rumah tangga terhadap orang dalam 
lingkup rumah tangganya, dengan cara kekerasan fisik, kekerasan psikis, kekerasan seksual dan Penelantaran.

Ketika anak tersebut melanggar atau melakukan penelantaran terhadap kedua orang tuanya maka dia akan dikenakan sanksi dari hukum Islam dan hukum positif di Indonesia. Siksaan atau hukuman di dunia bagi anak yang durhaka kepada orang tua belum ditetapkan dalam syara' dan wewenang untuk menetapkannya diserahkan kepada ulil amr (Wardi Muslich; 2005). Maka hukuman atau siksaan yang digunakan adalah jarimah ta'zir. Jadi siksaan atau hukuman di dunia untuk anak yang menelantarkan orang tuapun serupa dengan hukuman di dunia bagi anak yang durhaka kepada orang tua, sebab penelantaran orang tua merupakan bentuk-bentuk perilaku durhaka anak terhadap orang tua. Makna ta'zir bisa juga diartikan mengagungkan dan membantu, seperti apa yang difirmankan Allah SWT dalam QS. Al-Fath (48): 8, maksudnya dari kata 'Tu'azziruubu' dalam ayat ini adalah mengagungkannya dan menolongnya (Wardi Muslich: 2005).

Ta'zir dalam bahasa Arab diartikan juga sebagai penghinaan; dikatakan 'Azzara Fulanun Fulaanan' yang artinya ialah bilamana Fulan yang pertama melakukan penghinaan terhadap Fulan kedua dengan motivasi memberi peringatan dan pelajaran kepadanya atas dosa yang dilakukan olehnya.Ta'zir adalah hukuman yang bersifat edukatif yang ditentukan oleh hakim atas pelaku tindak pidana atau pelaku perbuatan maksiat yang hukumannya belum ditentukan oleh syariat atau kepastian hukumnya belum ada (Sabiq; 1987).

Adapun yang dimaksud dengan arti ta'zir menurut terminologi fikih Islam adalah tindakan edukatif terhadap pelaku perbuatan dosa yang tidak ada sanksi hadd dan kifaratnya. Rahmat Hakim mengatakan bahwa ta'zir adalah jarimah yang sanksinya ditentukan penguasa (Saebani: 2013). Penelantaran orang tua termasuk dalam kekerasan kepada orang tua. Hukum Islam dan hukum positif di Indonesia pada hakekatnya sama-sama sebuah aturan. Aturan yang bersifat mengatur dan memaksa bagi anggotanya, akan tetapi dengan landasan dan tujuan yang berbeda, sehingga menimbulkan implikasi yang berbeda.

Dalam hukum Islam penelantaran orang tua termasuk dalam bentuk-bentuk tindakan durhaka terhadap orang tua ('uququl walidain)berikut adalah sanksi untuk anak yang menelantarkan orang tua:

Pertama, dosa besar yang paling besar, sebagaimana bahwa Rasulullah SAW (Al-Bukhari (no. 2654, 5976), Muslim (no. 87), Ahmad (V/36, 38), dan at-Tirmidzi (no. 1901, 2301, 3019):

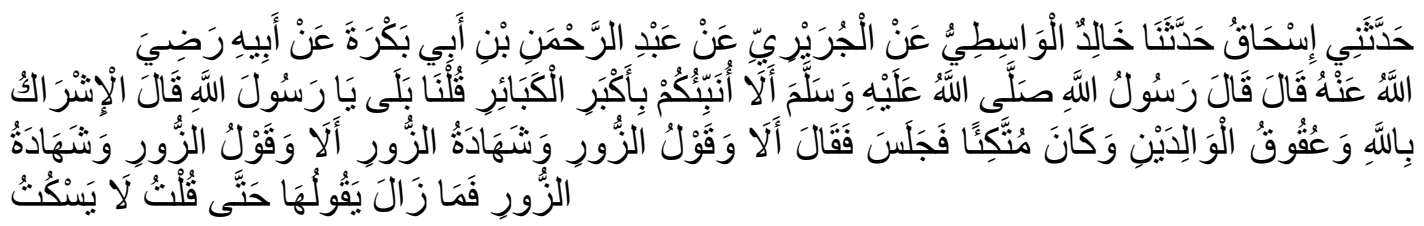

Kedua, segala amalnya tidak diterima oleh Allah SWT, sebagaimana bahwa Rasulullah SAW ath-Thabrani (no. 7547), Ibnu Abi 'Ashim, as-Sanah (no. 323): 


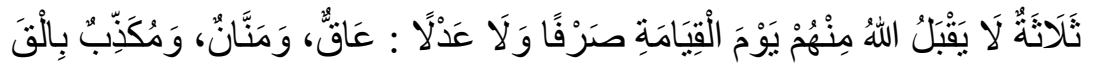

Ketiga, tidak akan masuk surga, sebagaimana bahwa Rasulullah SAW Muslim (no. 2551), Tirmidzi (no. 3545), Ahmad (no. 7451):

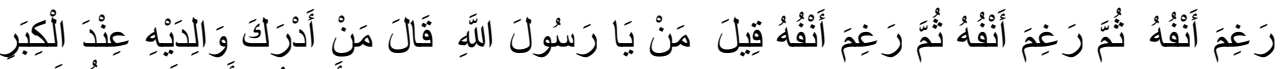



Dan HR. Hakim, Baihaqi, Ahmad (no. 2/134):

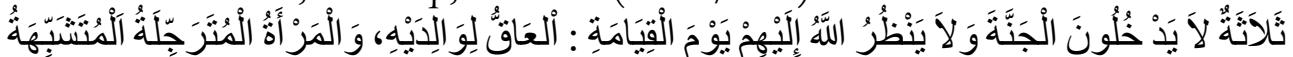

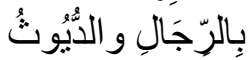

Ketiga, dibenci Allah SWT, sebagaimana bahwa Rasulullah SAW HR. atTirmidzi (no. 1899), al-Hakim (no. 7249), dan ath-Thabrani dalam al-Mu'jam alKabiir (no. 14368), dan al-Bazzar (no. 2394):

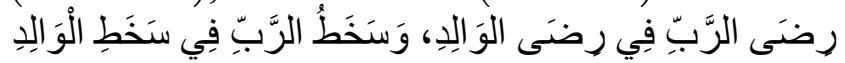

Keempat, Allah SWT percepat adzabnya di dunia, sebagaimana bahwa Rasulullah SAW HR. Al-Hakim (no. 7430), al-Bukhari dalam Al Adab Al Mufrad (no. 895):

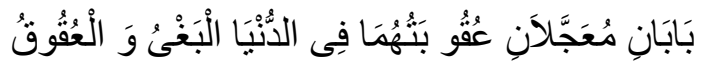

Adapun sanksi bagi pelaku penelantaran orang tua menurut hukum positif di Indonesia adalah sanksi pidana karena penelantaran adalah termasuk dalam tidak kekerasan sebagaimana yang tercantum pada Undang-Undang Nomor 23 Tahun 2004 tentang Penghapusan Kekerasan dalam Rumah Tangga pasal 5. Berikut adalah sanksi pidana bagi anak yang menelantarkan orang tuanya:

Pertama, dalam Pasal 26 Undang-undang Nomor 13 tahun 1998 tentang kesejahteraan lanjut usia yaitu

"Setiap orang atau badan/atau organisasi atau lembaga yang dengan sengaja tidak melakukan pelayanan dalam rangka peningkatan kesejabteraan sosial sebagaimana dimaksud dalam Pasal 14 Ayat (4), Pasal 19 Ayat (2) dan Ayat (3), padahal menurut bukum yang berlaku baginya ia wajib melakukan perbuatan tersebut, diancam dengan pidana kurungan selama-lamanya 1(satu) tabun atau denda sebanyak-banyaknya Rp.200.000.000,00 (dua ratus juta rupiah)".

Kedua, Pasal 304 KUHP adalah

"Barang siapa dengan sengaja menempatkan atau membiarkan seorang dalam keadaan sengsara, padahal menurut bukum yang berlaku baginya atau karena persetujuan dia wajib memberi kehidupan, perawatan atau pemeliharaan kepada orang itu, diancam dengan pidana penjara paling lama dua tabun delapan bulan atau pidana denda paling banyak empat ribu lima ratus rupiab".

Ketiga, dalam Pasal 49 Undang-undang Nomor 23 Tahun 2004 tentang penghapusan kekerasan dalam rumah tangga ialah

"Dipidana dengan pidana penjara paling lama 3 (tiga) tahun atau denda paling banyak Rp 
15.000.000,00 (lima belas juta rupiah), setiap orang yang:

a) Menelantarkan orang lain dalam lingkup rumah tangganya sebagaimana dimaksud dalam Pasal 9 Ayat (1);

b) menelantarkan orang lain sebagaimana dimaksud dalam Pasal 9 Ayat (2)”.

Seorang anak dapat dikenakan sanksi pidana apabila anak tersebut sudah dikatakan cakap hukum atau telah dewasa atau telah baligh. 
Qawwãm・ Volume 13 Nomor 1, Juni 2019

\section{Kesimpulan}

Adapun kesimpulan dari Skripsi yang berjudul "Penelantaran Orang Tua (Studi Komparatif Hukum Islam Dan Hukum Positif Di Indonesia)", yaitu sebagai berikut:

1. Penelantaran orang tua perspektif hukum Islam dan hukum positif di Indonesia adalah dilarang karena sebagaimana dalam hukum Islam menelantarkan orang yang menjadi tanggungannya hukumnya adalah dosa, sedangkan dalam hukum positif di Indonesia penelantaran adalah termasuk tidak kekerasan sebagaimana Undang-Undang Nomor 23 Tahun 2004 tentang Penghapusan Kekerasan dalam Rumah Tangga pasal 5. Bukan hanya itu saja karena setiap orang tua memiliki hak atas anaknya yang harus dipenuhi oleh anak tersebut.

2. Sanksi bagi pelaku penelantaran orang tua perspektif hukum Islam yaitu dosa besar, segala amalnya tidak diterima oleh Allah SWT, tidak akan masuk surga, dibenci Allah SWT, dan hukumannya dipercepat didunia yaitu dengan dikenakan jarimah ta'zir. Sedangkan sanksi bagi pelaku penelantaran orang tua perspektif hukum positif di Indonesia adalah sanksi pidana yaitu;

Pertama, dalam Pasal 26 Undang-undang Nomor 13 tahun 1998 tentang kesejahteraan lanjut usia yaitu "Setiap orang atau badan/ atau organisasi atau lembaga yang dengan sengaja tidak melakukan pelayanan dalam rangka peningkatan kesejabteraan sosial sebagaimana dimaksud dalam Pasal 14 Ayat (4), Pasal 19 Ayat (2) dan Ayat (3), padahal menurut bukum yang berlaku baginya ia wajib melakukan perbuatan tersebut, diancam dengan pidana kurungan selama-lamanya 1 (satu) tabun atau denda sebanyakbanyaknya Rp.200.000.000,00 (dua ratus juta rupiah)”.

Kedua, Pasal 304 KUHP adalah "Barang siapa dengan sengaja menempatkan atau membiarkan seorang dalam keadaan sengsara, padahal menurut bukum yang berlaku baginya atau karena persetujuan dia wajib memberi kehidupan, perawatan atau pemelibaraan kepada orang itu, diancam dengan pidana penjara paling lama dua tabun delapan bulan atau pidana denda paling banyak empat ribu lima ratus rupiah".

Ketiga, dalam Pasal 49 Undang-undang Nomor 23 Tahun 2004 tentang penghapusan kekerasan dalam rumah tangga ialah "Dipidana dengan pidana penjara paling lama 3 (tiga) tabun atau denda paling banyak Rp 15.000.000,00 (lima belas juta rupiah), setiap orang yang:

a) Menelantarkan orang lain dalam lingkup rumah tangganya sebagaimana dimaksud dalam Pasal 9 Ayat (1);

b) menelantarkan orang lain sebagaimana dimaksud dalam Pasal 9 Ayat (2)".

\section{Daftar Pustaka}

Al-‘Adawi Mushthofa bin, Fiqih Birrul Walidain, Solo: Al-Qowam, 2005.

Al-Fahham Muhammad, Berbakti Kepada Orang Tua Kunci Kesuksesan dan Kebahagiaan Anak, Bandung: Irsyad Baitus Salam, 2006.

Al-Faruq, Asadulloh, Hukum Pidana dalam Sistem Hukum Islam, Bogor: Ghalia Indonesia, 2009.

al-Ghamidi, Abu Hamzah Abdul Latief, Stop KDRT Membuang Prahara Di Rumah Kita dengan Kembali kepada Tuntunan Islam, Jakarta: Pustaka Imam Syafi'i, 2010. 
Ali, Mahrus, Dasar-dasar Hukum Pidana, Jakarta: Sinar Grafika, 2015.

Al-Iraqi Butsainah As-Sayyid, Air Mata Orang Tua Karena Kedurhakaan anaknya, Waringinrejo: Qiblatuna, 2014.

Al-Juzairi, Syekh Abdurrahman, Fikih Empat Mą̧bab, Jilid 3, Jakarta: Pustaka Al-Kausar, 2017.

Apeldoorn, L.J. Van, Pengantar Ilmu Hukum, Jakarta: PT. Pradnya Paramita, 1996.

ar-Rifa'i Muhammad Nasib, Ringkasan Tafsir Ibnu Katsir, jilid 3, Jakarta: Gema Insani, 2012.

Asy-Syifa, Al-Quran dan Terjemahan, Semarang: Raja Publishing, 2011.

Ath-Thahir Hamid Ahmad, Nestapa Anak Durhaka, Surabaya: Pustaka Yassir, 2014.

Amiruddin, Pengantar Metode Penelitian Hukum. Jakarta: Pt Raja Grafindo, 2004.

Efendy, Ferry dan Makhfudli, Keperawatan Kesehatan Komunitas: Teori dan Praktik dalam Djamarah, Syaiful Bahri, Pola Asub Orang Tua dan Komunikasi dalam Keluarga: upaya membengun citra membentuk pribadi anak, Jakarta: Rineka Cipta, 2014.

Gunawan Heri, Keajaiban Berbakti Kepada Kedua Orang Tua, Bandung: PT. Remaja Rosdakarya, 2014.

Hakim, Rahmat, Hukum Pidana Islam, Bandung: Pustaka Setia, 2000.

Hasan, Mustofa dan Beni Ahmad Saebani, Hukum Pidana Islam (Fiqh Jinayah), Cet. 1, Bandung: Pustaka Setia, 2013.

Hasan: HR. at-Tirmidzi (no. 1899), al-Hakim (no. 7249), dan ath-Thabrani dalam al-Mu’jam al-Kabiir (no. 14368), dan al-Bazzar (no. 2394).

Hasan: HR. Hakim, Baihaqi, Ahmad (no. 2/134).

HR. Muslim (no. 2551), Tirmidzi (no. 3545), Ahmad (no. 7451).

Ihromi, T.O, Bunga Rampai Sosiologi Keluarga (Jakarta: Yayasan Obor, 1999)

Imaniyati, Neni, Sri, dan Panji Adam, Pengantar Hukum Indonesia: Sejarah dan Pokok-pokok Hukum Indonesia, Jakarta: Sinar Grafika, 2018.

Irfan, M. Nurul, Hukum Pidana Islam, Jakarta: Amzah, 2016.

Jawas, Yazid bin Abdul Qadir, Birrul Walidain Berbakti Kepada Kedua Orang Tua, Jakarta: Pustaka Imam Asy-Syafi'i, 2018.

Keperawatan, Jakarta: Salemba Medika, 2009

Jahja, Yudrik. Psikologi Perkembangan. Jakarta: Kencana. 2011.

Pustaka.

Kansil, C.S.T. Pengantar Ilmu Hukum Dan Tata Hukum Indonesia. Jakarta Balai

Koenjaraninggrat, Metode-Metode Penelitian Masyarakat. Jakarta: Bina Asara, 2002.

Raco, J, R. Metode Penelitian Kualitatif: Jenis, Karakter, Dan Keunggulannya, Jakarta: PT Grasindo. 2010.

Kitab Undang-undang Hukum Perdata

Kitab Undang-undang Hukum Pidana

Lamintang dan Franciscus Theojunior Lamintang, Dasar-dasar Hukum Pidana Di Indonesia, Jakarta: Sinar Grafika, 2014.

Luhulima, Achie Sudiarti, Pemahaman Bentuk - Bentuk Tindak Kekerasan Terbadap 
Qawwãm・ Volume 13 Nomor 1, Juni 2019

Perempuan Dan Alternatif Pemecahannya, Jakarta: PT.Alumni, 2000.

2007

Notoatmodjo, S, Promosi Kesehatan dan Ilmu Perilaku, Jakarta: Rineka Cipta,

Mertokusumo, Sudikno, Mengenal Hukum Suatu Pengantar, Cet. IV, Yogyakarta: Liberty Yogyakarta, 2008.

Muslich, Ahmad Wardi, Hukum Pidana Islam, Cet. 2, Jakarta: Sinar Grafika, 2005

Sabiq, Sayyid, Fiqh Sunnah 10, Bandung: PT. Alma'arif, 1987.

Salim Abdurrasyid Abdul Aziz, Syarah Bulughul Maram, Surabaya: Halimjaya, 2010 .

Saputra, Mighael Agus , Asas-asas Hukum Perdata, 4 Desember 2014, http://luhurbudiawanilmuhukum.blogspot.com/2014/12/asas-asas-hukumperdata.html, Diakses 26 Juli 2019.

Shahih dan hasan: HR. Ahmad (no. 441), Sunan Nasa `i (no. 2515) dan di hasankan oleh Al-Albani dalam Silsilah Hadits Shahihnya (no. 675).

Shahih: HR. Al-Bukhari (no. 2654, 5976), Muslim (no. 87), Ahmad (V/36, 38), dan at-Tirmidzi (no. 1901, 2301, 3019).

Shahih: HR. Al-Bukhari (no. 2856, 5967), Muslimah (no. 30 [48], 30 [49]), dan at-Tirmidzi (no. 2643).

Shahih: HR. Al-Hakim (no. 7430), al-Bukhari dalam Al Adab Al Mufrad (no. $895)$.

Shahih: HR. ath-Thabrani (no. 7547), Ibnu Abi 'Ashim, as-Sanah (no. 323).

Shahih: HR. Bukhari (no. 5518), dan Muslim (no. 3239).

Shihab M. Quraish, Tafsir Al-Misbah, Vol 12, Jakarta: Lentera Hati, 2011.

Sudira, I Ketut, Mediasi Penal Perkara Penelantaran Rumah Tangga, Yogyakarta: UII Press Yogyakarta, 2016.

Sulaiman, Abu Dawud bin al-Asy'as bin Ishaq bin Basyir bin Syaddad bin 'Amr al-Azdi as-Sijistani, Sunan Abi Dawud, jilid II, Beirut: Maktabah al-'Isriyyah, t.t.

Undang-undang No. 1 Tahun 1974 tentang Perkawinan.

Undang-undang No. 23 tahun 2002 tentang perlindungan anak.

Undang-undang Nomor 13 tahun 1998 tentang Kesejahteraan Lanjut Usia.

Undang-undang Nomor 23 Tahun 2004 tentang Penghapusan Kekerasan Dalam Rumah Tangga.

Wahidin, Khaerul dan Taqiyuddin Masyhuri. Metode Penelitian (Prosedur dan Teknik Menyusun Skripsi Makalah dan Book Raport). Cirebon: CV Alawiyah, 2002.

www.Id.wikipedia.org/wiki/kekerasan dalam rumahtangga,pengertian, Penelanran, diakses pada hari minggu, 3 Juli 2019, 20:33 WIB. 